\title{
Rectocutaneous fistula with Fournier's gangrene, a rare presentation of rectal cancer
}

\author{
Simon Rajendran, ${ }^{1}$ Ata Khan, ${ }^{1}$ Micheal Murphy, ${ }^{2}$ Deirdre ' Hanlon $^{1}$ \\ ${ }^{1}$ General Surgery Department, South Infirmary Victoria Hospital, Cork, Ireland; \\ ${ }^{2}$ Radiology Department, South Infirmary Victoria University Hospital, Cork, Ireland \\ Correspondence to Dr Simon Rajendran, simonrajendran@gmail.com
}

\section{DESCRIPTION}

73-year-old female presented with foul smelling discharge from the perianal area. Examination revealed cutaneous fistula, discharging faeculent material. CT showed a large rectal tumour with gross evasion of the perianal tissues, with extension into vagina and subcutaneous tissue bilaterally and a large volume of air in tissues (figure 1). Laparotomy demonstrated rectal tumour, Fournier's grangrene with abscess cavities on both sides, disruption of the lower end of the rectum and a fistulating tract into the vagina (figure 2). Colostomy and extensive debridement of necrotic material was performed. Further, debridement and delayed primary closure were carried out, after which she commenced radiotherapy.

Colocutaneous fistulae can result from diverticulitis, Crohn'disease, appendicitis, pancreatitis, radiation therapy and malignancy, while the surgical treatment of these conditions account for the majority of cases. ${ }^{1}$ Fistulae from malignancy are rarely seen today because most colon cancers are diagnosed and treated at an earlier stage. Investigations include enema studies or CT. Management involves proximal diversion and treatment of pathology.
Fournier's gangrene is a necrotising fasciitis, involving the perineum and genital organs. ${ }^{2}$ It was described by Baurienne in 1764 and formally named by Fournier in 1883. The infection is usually polymicrobial and synergistic. Risk factors include diabetes, alcohol abuse and immunosuppression. Diagnosis is clinical, but radiological investigations may be helpful. CT outlines the extent and source of infection. Treatment consists of antibiotics and aggressive surgical debridement of all necrotic tissue. ${ }^{2}{ }^{3}$ Urinary or faecal diversion might be required to prevent contamination or to treat an underlying condition.

Acknowledgements Female Surgical ward and theatre, South Infirmary Victoria Hospital

Competing interests None.

Patient consent Obtained.

\section{REFERENCES}

1. Lavery IC. Colonic fistulas. Surg Clin North Am 1996;76:1183-90.

2. Eke N. Fournier's gangrene: a review of 1726 cases. Br J Surg 2000;87:718-28.

3. Endorf FW, Supple KG, Gamelli RL. The evolving characteristics and care of necrotizing soft-tissue infections. Burns 2005;31:269-73.
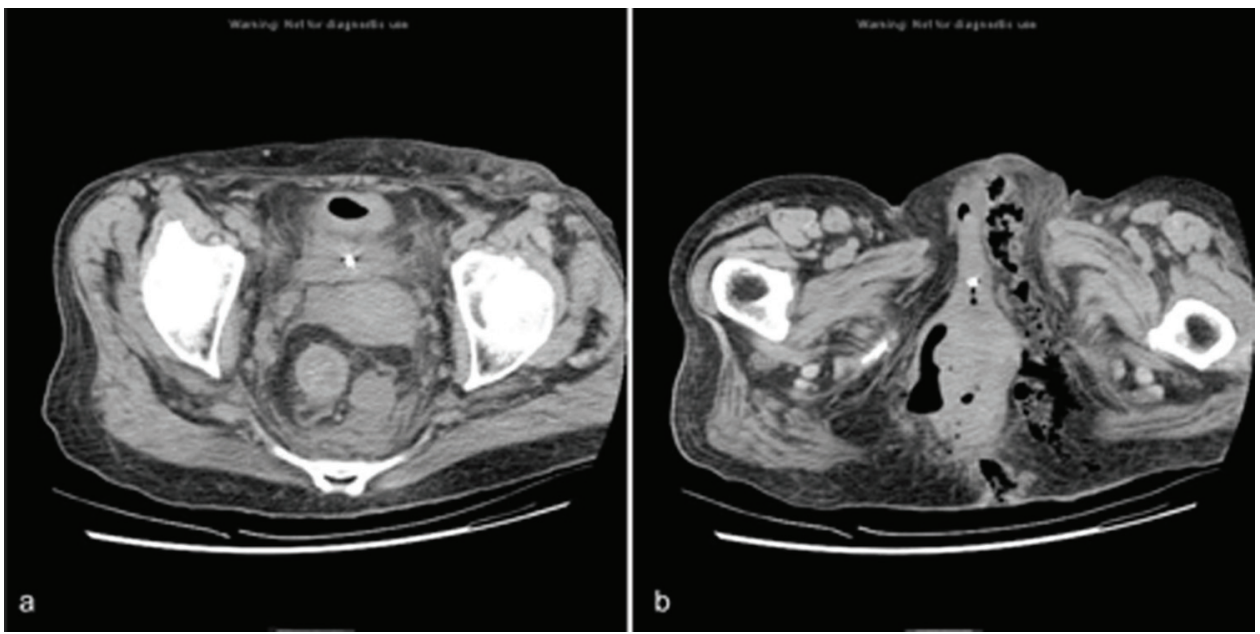

Figure 1 CT demonstrating a large rectal tumour $(A)$ with gross evasion of the perianal tissues, extension into the vagina and subcutaneous tissue bilaterally and a large volume of air in the tissues (B). 


\section{BMJ Case Reports}
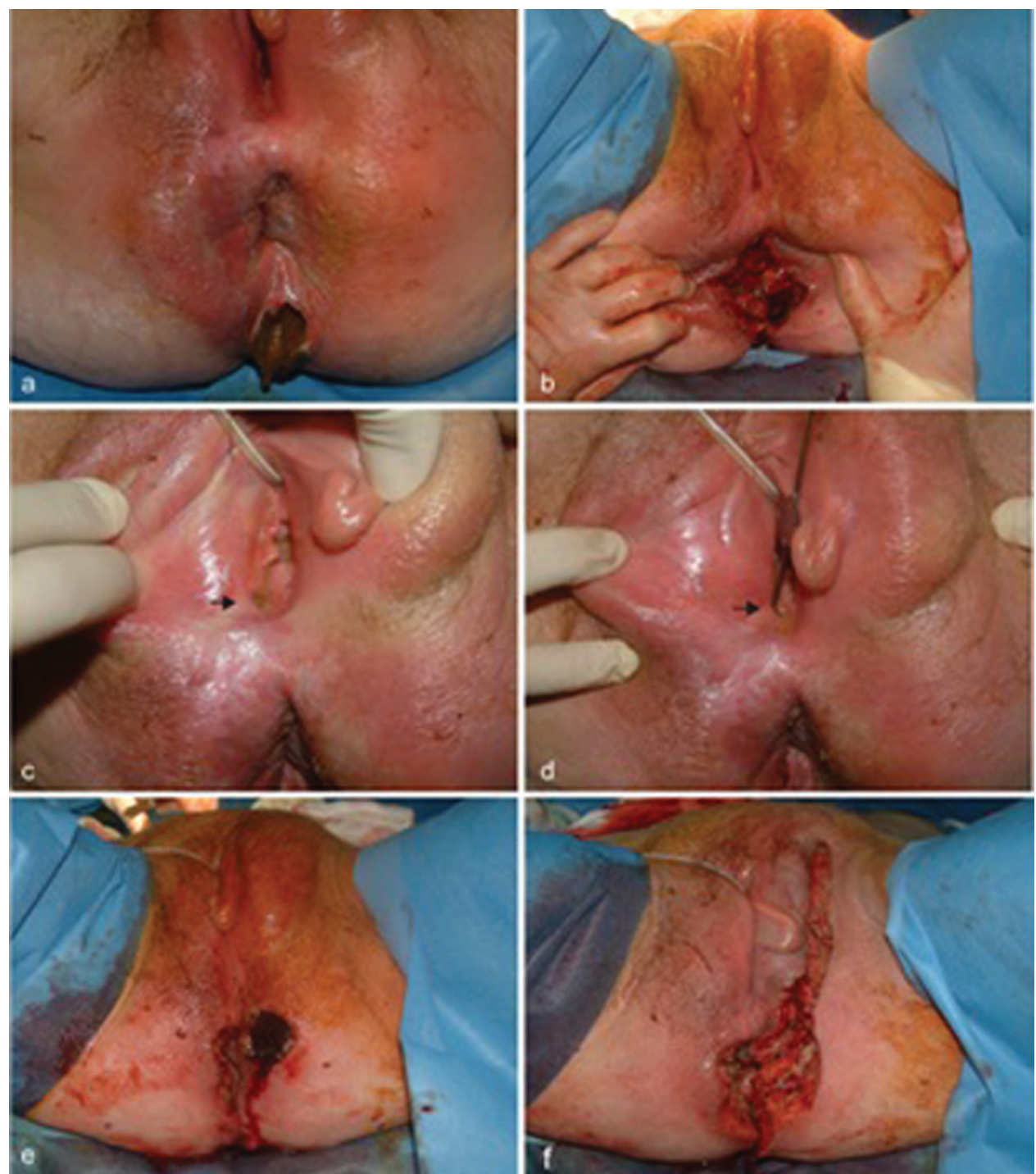

Figure 2 Rectocutaneous fistula $(A)$, rectal tumour $(B)$ with disruption of lower end of rectum. Fistulating tract into the vagina (arrow, C) explored with fistula probe (arrow, D). Fournier's gangrene $(E)$, requiring extensive debridement of necrotic tissue (F).

This pdf has been created automatically from the final edited text and images.

Copyright 2011 BMJ Publishing Group. All rights reserved. For permission to reuse any of this content visit http://group.bmi.com/group/rights-licensing/permissions.

BMJ Case Report Fellows may re-use this article for personal use and teaching without any further permission.

Please cite this article as follows (you will need to access the article online to obtain the date of publication)

Rajendran S, Khan A, Murphy M, O'Hanlon D. Rectocutaneous fistula with Fournier's gangrene, a rare presentation of rectal cancer. BMJ Case Reports 2011;10.1136/bcr.06.2011.4372, date of publication

Become a Fellow of BMJ Case Reports today and you can:

- Submit as many cases as you like

- Enjoy fast sympathetic peer review and rapid publication of accepted articles

Access all the published articles

- Re-use any of the published material for personal use and teaching without further permission

For information on Institutional Fellowships contact consortiasales@bmjgroup.com

Visit casereports.bmj.com for more articles like this and to become a Fellow 